\title{
Changes in the Concentrations of Glucose, Free Fatty Acids, Insulin and Ketone Bodies in the Blood during Sodium $\beta$-Hydroxybutyrate Infusions in Man
}

\author{
E. Balasse and H.A. Ooms
}

Medical Clinic and Departments of Experimental Medicine and Clinical Chemistry, University of Brussels

Received: September 27, 1967

Summary. Sodium $\beta$-hydroxybutyrate was infused for $1.5 \mathrm{~h}$ in 8 normal subjects, at a constant rate of 5 mmoles/ $\mathrm{kg} / \mathrm{h}$. Equimolar amounts of sodium chloride were infused in 5 control subjects. - The induced hyperketonaemia provoked the following changes in peripheral blood: a fall in glycaemia $(15 \mathrm{mg} / 100 \mathrm{ml}$ ) and in plasma NEFA concentration $(50 \%)$ without concomitant modifications of insulin concentrations. These results indicate that the glucose and NEFA changes observed are not mediated by a pancreatic stimulation.

Modifications des concentrations de glucose, d'acides gras libres, d'insuline et de corps cétoniques dans le sang pendant des perfusions de $\beta$-hydroxybutyrate de sodium chez l'homme

Résumé. Les auteurs ont étudié chez 8 sujets normaux les effets d'une perfusion de $\beta$-hydroxy-butyrate de sodium $(5 \mathrm{~m} \mathrm{~mol} / \mathrm{kg} / \mathrm{h}$ pendant $1.5 \mathrm{~h}$ ) sur la concentration sanguine en glucose, en acides gras libres, en corps cétoniques et en insuline dans le sang 'voineux périphérique. Cinq sujets témoins ont été perfusés à l'aide de solution équimolaires de $\mathrm{NaCl}$. - L'hypercétonémie provoque une chute de la glycémie d'environ $15 \mathrm{mg} / 100 \mathrm{ml}$, une chute des NEFA atteignant $50 \%$, sans modifications concommi- tantes de l'insulinémie. Ces résultats plaident contre l'intervention d'une stimulation pancréatique dans la chute de la glycémie et dos NEFA.

Anderungen der Glucose-, FFS-, Insulin- und Ketokörper-Konzentrationen unter einer Natrium- $\beta$-hydroxybutyrat-Infusion beim Menschen

Zusammenfassung. Natrium- $\beta$-hydroxy-butyrat wurde 8 Normalpersonen während 1.5 Std bei konstanter Geschwindigkeit von $5 \mathrm{mMol} / \mathrm{kg} / \mathrm{Std}$ infundiert. 5 Kontrollpersonen erhielten äquimolekulare Mengen einer Kochsalzlösung. - Die so bewirkte Erhöhung der KetokörperSpiegel führte im peripheren Blut zu folgenden Veränderungen: Absinken des Blutzuckers um $15 \mathrm{mg} \%$, Abfall der Plasma-FFS auf die Hälfte ohne gleichzeitige Änderung der Insulinspiegel. Diese Ergebnisse sprechen dafür, daß die Änderung der Glucose- und FFS-Konzentrationen nicht durch eine Stimulierung des Pankreas ausgelöst wird.

Key-words: Glucose, free fatty acids, insulin, ketone bodies, sodium- $\beta$-hydroxybutyrate.

\section{Introduction}

In a recent work performed on dogs [1], we observed that sodium $\beta$-hydroxybutyrate (Na $\beta$-OH-B) infusions provoke a decrease in blood sugar and plasma NEFA concentrations together with a small, transient increase in the insulin concentration of peripheral blood. By the technique of isotope dilution using glucose- $1 .{ }^{14} \mathrm{C}$, we showed that hypoglycaemia was only due to a reduction of hepatic glucose output without any modification of the rate of peripheral utilization of glucose. Data available at present regarding the action of insulin on the output of glucose from the liver allowed us to conclude that the observed changes in blood glucose were not mediated by the small changes in blood insulin. Experiments with palmitate-1 $1{ }^{14}$ Crevealed that the fall of NEFA was the consequence of both an inhibition of their production by adipose tissue and an increase in their peripheral uptake. The role of insulin in these mechanisms was also questionable.

In the present work, which was performed in man, we have reëvaluated the eventual role of insulin in the modifications of blood glucose and NEFA induced by Na $\beta$-OH-B.

\section{Materials and Methods}

Thirteen normal subjects of both sexes, aged 14-50 (mean: 34 years) were examined.
An aqueous solution of Na DL- $\beta$-OH-B was infused into eight of these through a peripheral vein at a rate of $5 \mathrm{mmoles} / \mathrm{kg} / \mathrm{h}$ for $1.5 \mathrm{~h}$. The total volume infused was $500 \mathrm{ml}$ in every case.

Blood samples for estimation of glucose, NEFA, insulin, ketones and haematocrit were withdrawn from an antecubital vein on the opposite side. In 2 subjects, measurements of arterial pH were performed. The bladder was emptied before the tests and urine was collected at the end of the infusions for determination of the urinary ketone excretion. The solutions were sterilized prior to administration by filtration through a Millipore filter (diam. $0.45 \mu$ ). Their $\mathrm{pH}$ varied according to the concentration; for example, the $\mathrm{pH}$ of a solution prepared for a subject weighing $70 \mathrm{~kg}$ ( $66 \mathrm{~g}$ $\mathrm{Na} \beta-\mathrm{OH}-\mathrm{B} / 500 \mathrm{ml}$ ) was 8.35 .

Five subjects taken as controls were infused in the same experimental conditions with equimolar amounts of $\mathrm{NaCl}$; in these experiments, blood analyses were limited to glycaemia, NEFA concentration and haematocrit.

Some patients from both the treated and the control groups complained of slight headache; all were thirsty during and after the infusion as a consequence of the hypertonicity of the injected solutions; they were allowed to drink water ad libitum during the tests. 
Chemical determinations. Total blood glucose: HoFfman's method [7], adapted to the Technicon autoanalyser; plasma NEFA: TrovT's modification [16] of DoLE's technique [3], this procedure reducing the interference caused by $\mathrm{Na} \beta$-OH-B [14]; plasma insulin (I.R.I.): method of MorgAN and LAZAROW [12]; total ketones bodies: estimation both in urine (after a 1:10 dilution) and in plasma according to a modification [8] of MICHAELs' method [11], the results being expressed as equivalents of acetone.

\section{Results}

1. $N a \beta-O H-B$ treated subjects. The amount of $\mathrm{Na} \beta$-OH-B lost in urine during the test reached 4.5 to $9.2 \%$ (mean $6.4 \%$ ) of the injected dose.

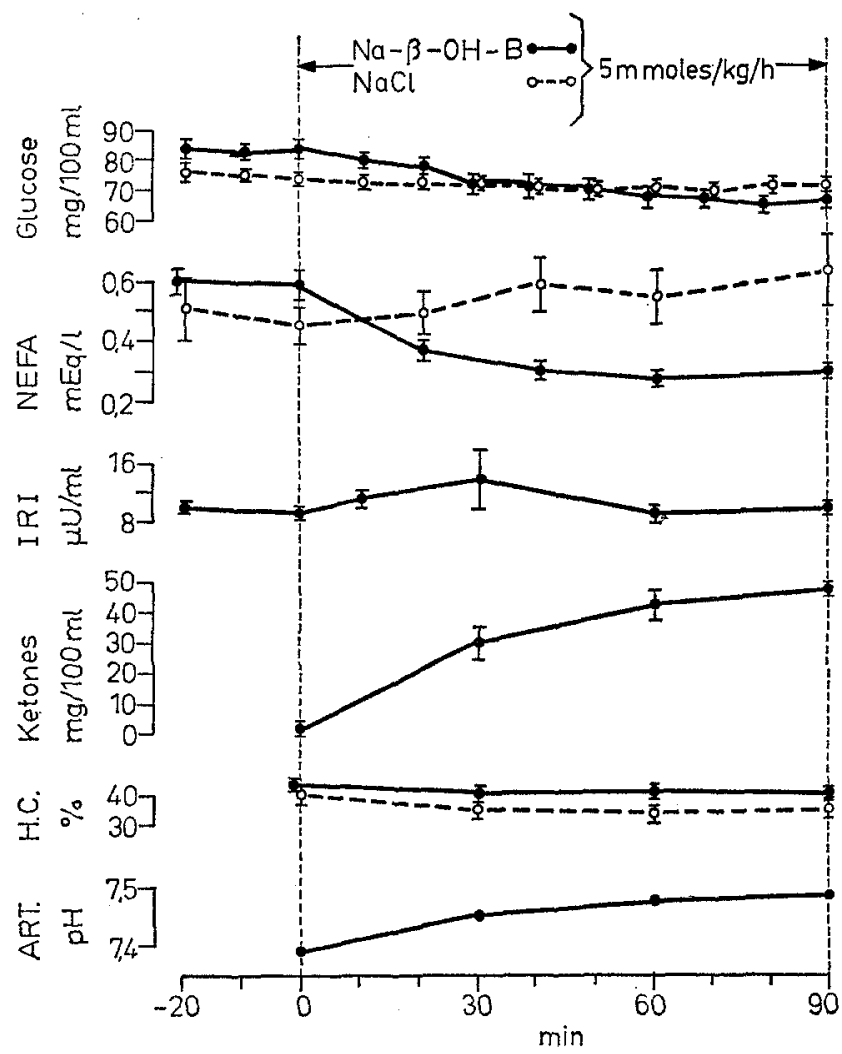

Fig. 1. Modifications induced by $\mathrm{Na} \beta-\mathrm{OH}-\mathrm{B}$ infusions in man

- - mean results for 8 subjects \pm S.E.M.

o- - - Mean results for 5 control subjects \pm S.E.M.

The other results are represented in the figure: the infusion of $\mathrm{Na} \beta$-OH-B provoked the following changes (mean values):

a) an important increase in ketonaemia up to $47.6 \mathrm{mg} / 100 \mathrm{ml}$; b) a slight alkalosis, arterial $\mathrm{pH}$ rising from 7.39 to 7.48 ; c) a small decrease in haematocrit from $43 \%$ to $40 \%$; d) a fall in blood sugar from $84 \mathrm{mg} / 100 \mathrm{ml}$ during the control period to $69 \mathrm{mg} /$ $100 \mathrm{ml}$ during the last $30 \mathrm{~min}$ of the infusion; using Student's $t$ test, statistical significance has been checked at 30,60 and $90 \mathrm{~min}$ and found to be at 1 percent level; e) a $50 \%$ fall in plasma NEFA whose concentration decreased from $0.59 \mathrm{mEq} / 1$ during the control period to $0.28 \mathrm{mEq} / 1$ at the end of the infusion (significant at $1 \%$ percent level); f) a lack of change in insulin concentration in peripheral blood.

2. Control subjects. As shown in the figure, no significant changes occured in either the blood sugar or the plasma NEFA concentrations. A slight decrease in haematocrit was noted for $\mathrm{Na} \beta$-OH-B infusions.

\section{Discussion}

The observed hypoglycaemia is consistent with data obtained in man by FAJANs et al. with acetoacetate infusions [4]; similar findings were made in dogs by Neptune et al. [13], Mebane et al. [10], Feuts et al. [5], and Balasse et al. [1].

Madison et al. [9] noticed that $\mathrm{Na} \beta-\mathrm{OH}-\mathrm{B}$ infusions in dogs produced an important and prolonged increase in insulin concentration in pancreatic vein. In our experience, during infusions at a rate of $5 \mathrm{mmoles} / \mathrm{kg} / \mathrm{h}$, an insulinic response was hardly detectable in peripheral blood of dogs [1], and not at all in man, as is shown by the present results. This is in agreement with data from FaJans et al. [4]. These observations might of course be interpreted as if the extra insulin secreted by the pancreas was completely trapped by the liver. But even this hypothesis cannot explain the observed hypoglycaemia. We have shown, indeed, [1] that the hypoglycaemic action of $\mathrm{Na}$ $\beta$-OH-B in dogs is due only to a reduction in liver glucose output, and it has been proved that during insulin hypoglycaemia, the inhibitory influence of insulin on the output of glucose by the liver is always overwhelmed by the stimulating effect of peripheral hypoglycaemia $[6,15]$. Therefore, a direct inhibitory action of $\mathrm{Na} \beta$-OH-B on the output of glucose by the liver must be considered.

The present observation of a decrease in NEFA concentration induced by $\mathrm{Na} \beta-\mathrm{OH}-\mathrm{B}$ in man is in agreement with similar results obtained in dogs [10]. Our data do not support the hypothesis of an insulinic effect, as proposed by Madisor et al. [9], since no modification of insulin concentration occured in peripheral blood. The decrease in NEFA concentration observed can reasonably be related to a direct inhibitory effect of $\mathrm{Na} \beta$-OH-B on lipolysis at the level of adipose tissue, as it has been proved in vitro (2).

In our experiments using ketone infusions, the ketone levels obtained were close to those observed during prolonged starvation: the mean plasma ketone levels estimated in 5 starved patients, who were moderately obese, reached $34 \mathrm{mg} / 100 \mathrm{ml}$ and $37 \mathrm{mg} / 100 \mathrm{ml}$ after 8 and 12 days respectively of fasting.

Madison et al. [9] have suggested some interesting implications of the metabolic influence of ketone bodies during fasting. Hyperketonaemia might be a factor responsible for the hypoglycaemia observed during fasting, which, together with a reduction of 
peripheral glucose utilization, could contribute to the sparing of glucose for use by the brain. Moreover, the high ketone levels could prevent an excessive elevation of the NEFA, and thereby prevent fatal ketoacidosis during prolonged starvation.

Our data provide further information supporting these views but suggest that these control mechanisms are not mediated through a pancreatic stimulation.

\section{References}

1. Balasse, E., E. Couturier, and J.R.M. Franckson: Influence of Sodium $\beta$-Hydroxybutyrate on glucose and free fatty acid metabolism in normal dogs. Dia. betologia $3,488-493$ (1967).

2. BJörntorp, P.: The effect of Beta-Hydroxy-Butyric acid on glycerol outflow from adipose tissue in vitro. Metabolism 15, 191-193 (1966).

3. Dole, V.P.: A relation between the non esterified fatty acids in plasma and the metabolism of glucose. J. clin. Invest. 35, 150-154 (1956).

4. FaJans, S.S., J.C. Floyd Jr., R.F. KNoPF, and J.W. ConN.: A comparison of leucine and acetoacetate-induced hypoglycemia in man. J. clin. Invest., 43, 2003-2008 (1964).

5. Ferts P.W., O.B. Crofford, and C.R. Park : Effect of infused ketone bodies on glucose utilisation in the dog. J. elin. Invest. 43, 638-646, (1964).

6. Franckson, J.R.M., H.A. Ooms, R. Bellens, Y. Arnould, and V. Conard : Action d'une perfusion intraportale d'insuline sur la glycémie artérielle et le débit glucosé hépatique du chien. Arch. int. Pharmacodyn. 142, 293-311 (1963).

7. HowfmanN, W.S.: A rapid photoelectric method for the determination of glucose in blood and urine. $\mathrm{J}$. biol. Chem. 120, $51-55$ (1937).

8. Johonson, R.E., F. Sargent II, and R. Passmore: Normal variations in total ketone bodies in serum and urine of healthy young men. Quart. J. exp. Physiol. 43, $339-344$ (1958).

9. Madison, L.L., D. Mebane, R.H. Unger, and A. LOCHNER: The hypoglycemic action of ketones. II. Evidence for a stimulatory feedback of ketones on the pancreatic Beta cells. J. clin. Invest. 43, 408-415 (1964).

10. Mebane, D., and L.L. Madison: Hypoglycemic action of ketones. I. Effects of ketones on hepatic glucose output and peripheral glucose utilisation. J. Lab. clin. Med. 63, 177-192. (1964).

11. Michaels, G.D., S. Margen, G. Luebert, and L.W. KinsenL: Studies in fat metabolism. I. The colorimetric determination of ketone bodies in biological fluids. J. clin. Invest. 30, 1483-1485 (1951).

12. Morgan, C.R., and A. Lazarow: Immunoassay of insulin; two antibody system. Diabetes 12, 115-126 (1963).

13. NePtune, E.M., Jr.: Changes in blood glucose during metabolism of $\beta$-Hydroxybutyrate. Amer. J. Physiol. 187, 451. (1956).

14. Parys, J., F. Barbirr, and A. Elewaut: Specificity of the free fatty acid titration by the method of Dole, modified according to Trout. Clin. Chem. 12, 767-770, (1966).

15. Tarding, F., and P. Schambye: The action of sulfonylureas and insulin on the glucose output from the liver of normal dogs. Endocrinology 36, 222-228 (1958).

16. Trout, D.L., E.H. Estes, and S.J. Friedbera: Titration of Free fatty acids of plasma: A study of Current Methods and a new modification. J. Lipid. Res. 1, 199 (1960).

\section{Dr. E. BALASSE}

Medical Clinic

and Department of

Experimental Medicine,

University of Brussels,

Brussels, Belgium 